\title{
Association study of Notch 4 polymorphisms with Alzheimer's disease
}

\author{
J-C Lambert, D Mann, J Harris, L Araria-Goumidi, M-C Chartier-Harlin, D Cottel, T Iwatsubo, \\ P Amouyel, C Lendon
}

J Neurol Neurosurg Psychiatry 2004;75:377-381. doi: 10.1136/jnnp.2003.017368

See end of article for authors' affiliations ......................

Correspondence to: Dr Jean-Charles Lambert, Unité INSERM 508 Institut Pasteur de Lille 1, rue du $\mathrm{Pr}$ Calmette BP 245, 59019 Lille Cedex, France; Jean-Charles.Lambert@ pasteur-lille.fr

Received 23 April 2003 In revised form: 13 June 2003 Accepted 21 June 2003

\begin{abstract}
Background: The NOTCH4 gene is located at 6p21.3, a site shown in several studies to have significant linkage with Alzheimer's disease.

Objective: To investigate the potential impact of two polymorphisms within this gene on the risk of developing Alzheimer's disease.

Methods: Genotyping of promoter and 5'-UTR polymorphisms was done in Scottish, English, and French populations. The potential functionality of the $5^{\prime}$-UTR polymorphism was assessed by testing its impact on $A \beta$ load in Alzheimer brains and also by undertaking electrophoretic mobility shift assays and transfection experiments.

Results: No association of the Notch4 polymorphisms alone with the disease was observed in any of the populations. However, an interaction of the $5^{\prime}-$ UTR C/T polymorphism with the $\varepsilon 4$ allele of the APOE gene was detected in United Kingdom populations but not in the French. No relation between the 5'-UTR polymorphism and $A \beta$ loads was detected overall or in the presence or absence of the $\varepsilon 4$ allele. No DNA protein specific binding was found with proteins from neuroblastoma, glioma, or astrocytoma cells, and no allele dependent transcriptional activity was detected.

Conclusions No association between two NOTCH4 polymorphisms alone and Alzheimer's disease was observed in the three populations, but there was evidence of an increased risk associated with the 5'-UTR CC genotype in $\varepsilon 4$ bearers in the United Kingdom. As no functionality for this polymorphism could be determined, it is likely that the interaction is spurious or results from a linkage disequilibrium of this $5^{\prime}$-UTR polymorphism with another marker elsewhere in the 6p21.3 locus.
\end{abstract}

A lzheimer's disease is a progressive neurodegenerative disorder that occurs predominantly in later life. While the genetics of early onset autosomal dominant forms of Alzheimer's disease are well characterised, our understanding of the more common late onset disorder remains much less complete. Susceptibility to these late onset forms appears polygenic and may also be dependent on environmental factors. To date, only the $\varepsilon 4$ allele of the apolipoprotein $\mathrm{E}$ gene (APOE) is recognised worldwide as a susceptibility gene for Alzheimer's disease, though this is not always necessary nor sufficient to cause the disease, indicating a role of other genes in susceptibility to this condition. ${ }^{1}$

Among the numerous loci brought to the fore by genome scans, evidence for a weak linkage to chromosome $6,{ }^{23}$ in the vicinity of the major histocompatibility complex $(\mathrm{MCH})$ at $6 \mathrm{p} 21.3$, has led to the investigation of several candidate genes at this locus. To date, the human leucocyte antigen (HLA)-A2 allele, ${ }^{45}$ and variations in the regulatory region of the tumour necrosis factor $\alpha$ (TNF $\alpha)$ gene, ${ }^{6}$ have been reported to produce a modest increase in the risk of developing Alzheimer's disease. However, conflicting data have not allowed definite exclusion or confirmation of the impact of HLA-A2 or TNF $\alpha$ polymorphisms on Alzheimer's disease risk, ${ }^{78}$ and it is still possible that these associations may result from a gene in close linkage to the HLA-A2 allele or TNF $\alpha$ promoter polymorphisms. Supporting this possibility, other genes of interest located within the MCH 6p21.3 locus-such as HLA-DR3, CREBL1, the receptor for advanced glycosylation end products (RAGE), or NOTCH4-may be considered as candidate genes for Alzheimer's disease.
In this report, we have focused on the NOTCH4 gene, as several lines of evidence suggest that notch family genes may be relevant to Alzheimer's disease processes. Indeed, much data are consistent with a role for Notch signalling in the maintenance of the neural stem cell. ${ }^{9}$ In neurones, this signalling regulates the extension and elaboration of neurites in vitro. ${ }^{10}$ In humans, missense mutations of the NOTCH3 gene segregate with CADASIL (cerebral autosomal dominant arteriopathy with subcortical infarcts and leucoencephalopathy), a form of dementia with stroke. ${ }^{11}$ Finally, the NOTCH4 gene has recently been described as a risk factor for schizophrenia, ${ }^{12}$ even if this observation was not systematically replicated. ${ }^{13}$

Collectively, these data have led us to assess the impact of two polymorphisms in the NOTCH4 gene on the risk of developing Alzheimer's disease in two independent British and French populations.

\section{METHODS}

Study populations

We studied 255 British cases of Alzheimer's disease. They were all white, with a mean (SD) age at onset of 63.0 (11.0) years, and $54.4 \%$ were male. These were ascertained from two United Kingdom centres-the central belt of Scotland

Abbreviations: ADRDA, Alzheimer's Disease and Associated Disorders Association; ATCC, American Tissue Culture Collection; DSM-III-R, Diagnostic and Statistical Manual of Mental Disorders, 3rd edition, revised; EMSA, electrophoretic mobility shift assay; $\mathrm{MCH}$, major histocompatibility complex; NINDS, National Institute of Neurological and Communicative Disorders and Stroke 
Table 1 Allele and genotype distribution of the rs 387071 NOTCH 4 polymorphism in the British population

\begin{tabular}{|c|c|c|c|c|c|c|}
\hline \multirow[b]{2}{*}{ rs387071 } & \multirow[b]{2}{*}{$\mathrm{n}$} & \multicolumn{2}{|c|}{ Allele distribution (\%) } & \multicolumn{3}{|c|}{ Genotype distribution (\%) } \\
\hline & & G & A & GG & GA & AA \\
\hline \multicolumn{7}{|c|}{$\begin{array}{l}\text { Scotland, UK } \\
\text { Alzheimer's disease }\end{array}$} \\
\hline cases & 140 & $234(0.84)$ & $46(0.16)$ & $97(0.69)$ & $40(0.29)$ & $3(0.02)$ \\
\hline Control & 293 & $477(0.81)$ & $109(0.19)$ & $194(0.66)$ & $89(0.30)$ & $10(0.04)$ \\
\hline \multicolumn{7}{|c|}{$\begin{array}{l}\text { Manchester, UK } \\
\text { Alzheimer's disease }\end{array}$} \\
\hline cases & 115 & $191(0.83)$ & $39(0.17)$ & $79(0.69)$ & $33(0.28)$ & $3(0.03)$ \\
\hline Control & 112 & $183(0.82)$ & $41(0.18)$ & $75(0.67)$ & $33(0.29)$ & $4(0.04)$ \\
\hline \\
\hline cases & 255 & $425(0.83)$ & $85(0.17)$ & $176(0.69)$ & $73(0.29)$ & $6(0.02)$ \\
\hline Control & 405 & $660(0.81)$ & $150(0.19)$ & $269(0.66)$ & $122(0.30)$ & $14(0.04)$ \\
\hline
\end{tabular}

( $\mathrm{n}=140,25 \%$ of whom had been confirmed as definite Alzheimer's disease, one case with early onset Alzheimer's disease), and Greater Manchester ( $\mathrm{n}=115,10 \%$ of whom had been confirmed as definite Alzheimer's disease). An independent population of 436 white French cases (age at onset, 68.2 (7.8); $39.0 \%$ male), all of whom were cases of probable Alzheimer's disease, was also studied.

Diagnoses of definite or probable Alzheimer's disease were established according to DSM-III-R and NINDCS-ADRDA criteria. Early and late onset cases were defined as those with onset before 65 or $\geqslant 65$ years of age, respectively.

Controls were defined as subjects without DSM-III-R dementia criteria, and with full integrity of their cognitive functions. The United Kingdom control population comprised 293 controls from Scotland and 112 from Manchester (total 405; age, 60.7 ( 14.5 ) years; $46.8 \%$ male), and there were 569 French controls (age, 72.1 (8.1) years; 39.2\% male).

Ethical approval was obtained for the study from the relevant ethics committees, along with informed consent from all participants or their relatives. The data were anonymised to ensure subject confidentiality.

\section{Brain samples}

Brains from a further 88 cases of definite Alzheimer's disease (age at onset, 65.2 ( 10.3 ) years; age at death, 73.5 (9.6) years; $49 \%$ male) were collected from the Greater Manchester area. DNA was extracted from the frozen brain tissues of these cases by standard methods. The proportion of tissue area occupied by $A \beta_{40}, A \beta_{42(43)}$, and total $A \beta\left(A \beta_{40}+A \beta_{42(43)}\right)$ was quantified in immunohistochemically stained sections from Brodmann areas $8 / 9$ of the frontal cortex, as previously reported. ${ }^{14}$

\section{Genotyping}

APOE, rs387071 (promoter G/A), and rs367398 (5'-UTR C/T) NOTCH4 genotypes were determined as previously described. ${ }^{15}{ }^{16}$ NOTCH4 polymorphisms were separated by 3452 bases and were not in linkage disequilibrium (data not shown). All the polymorphisms tested were in HardyWeinberg equilibrium.

\section{Statistical analysis}

Univariate analyses were done using Pearson's $\chi^{2}$ test. In the multivariate analysis, we tested the hypothesis that possession of rs387071 GG and rs367398 CC genotypes increased the risk of Alzheimer's disease (that is, 5' -UTR GG $v$ rs387071 GA+AA genotypes and rs367398 CC $v$ promoter CT+TT genotypes). The effect of the two homozygote variants on the risk for Alzheimer's disease was assessed using a multiple logistic regression model adjusted for age and sex. The amyloid load for patients with the rs367398 CC genotype was compared with that from those with rs367398 CT+TT genotypes using the Kruskal-Wallis non-parametric test, overall and with and without an allele $\varepsilon 4$.

Pairwise linkage disequilibrium coefficients were estimated in the control samples. Extended haplotype frequencies of the

Table 2 Allele and genotype distribution of the rs 367398 NOTCH 4 polymorphism in the British population

\begin{tabular}{|c|c|c|c|c|c|c|}
\hline \multirow[b]{2}{*}{ rs367398 } & \multirow[b]{2}{*}{ n } & \multicolumn{2}{|c|}{ Allele distribution (\%) } & \multicolumn{3}{|c|}{ Genotype distribution (\%) } \\
\hline & & C & $\mathbf{T}$ & $\mathrm{CC}$ & CT & $\pi$ \\
\hline \multicolumn{7}{|l|}{$\begin{array}{l}\text { Scotland, UK } \\
\text { Alzheimer's disease }\end{array}$} \\
\hline cases & 140 & $200(0.71)$ & $88(0.29)$ & $70(0.50)$ & $60(0.43)$ & $10(0.07)$ \\
\hline Control & 293 & $381(0.64)$ & $205(0.36)$ & $123(0.42)$ & $135(0.46)$ & $35(0.12)$ \\
\hline \multicolumn{7}{|l|}{$\begin{array}{l}\text { Manchester, UK } \\
\text { Alzheimer's disease }\end{array}$} \\
\hline cases & 115 & $164(0.71)$ & $66(0.29)$ & $58(0.50)$ & $48(0.42)$ & $9(0.08)$ \\
\hline Control & 112 & $151(0.67)$ & $73(0.33)$ & $51(0.45)$ & $49(0.44)$ & $12(0.11)$ \\
\hline \multicolumn{7}{|l|}{$\begin{array}{l}\text { Total } \\
\text { Alzheimer's disease }\end{array}$} \\
\hline cases & 255 & $364(0.71)$ & $154(0.29)$ & $128(0.50)$ & $108(0.42)$ & $19(0.08)$ \\
\hline Control & 405 & $532(0.66)$ & $278(0.34)$ & $174(0.43)$ & $184(0.45)$ & $47(0.12)$ \\
\hline
\end{tabular}


Table 3 Evaluation of the interaction of the rs 367398 CC genotype with the $\epsilon 4$ allele of the APOE gene

\begin{tabular}{|c|c|c|c|}
\hline & $\begin{array}{l}\text { APOE*Notch } \\
\text { (p value) }\end{array}$ & $\begin{array}{l}\mathrm{CC} \text { versus } \mathrm{CT}+\mathrm{T} \\
\left(\mathrm{OR} \text { in } \varepsilon 4^{-}\right)\end{array}$ & $\begin{array}{l}\text { CC versus } \mathrm{CT}+\Pi \mathrm{T} \text { (OR } \\
\text { in } \varepsilon 4^{+} \text {) }\end{array}$ \\
\hline $\begin{array}{l}\text { Scotland, } \\
\text { UK }\end{array}$ & 0.06 & $\begin{array}{l}0.98(0.54 \text { to } 1.78) \\
p<0.82\end{array}$ & $\begin{array}{l}2.15(1.11 \text { to } 4.20) \\
p<0.03\end{array}$ \\
\hline $\begin{array}{l}\text { Manchester, } \\
\text { UK }\end{array}$ & 0.04 & $\begin{array}{l}0.55(0.20 \text { to } 1.52) \\
p<0.25\end{array}$ & $\begin{array}{l}4.75 \text { (0.96 to } 23.60) \\
p<0.06\end{array}$ \\
\hline Total & 0.002 & $\begin{array}{l}0.83(0.53 \text { to } 1.30) \\
p<0.40\end{array}$ & $\begin{array}{l}2.65(1.55 \text { to } 4.55) \\
p<0.0004\end{array}$ \\
\hline
\end{tabular}

APOE* Notch indicates the significance level of the interaction term included in the logistic regression model.

$\mathrm{OR}$, odds ratio. Confidence intervals are in given parentheses.

two markers were estimated on collapsed data using the myriad haplotype algorithm described by McLean et al. ${ }^{17}$

\section{Electrophoretic mobility shift assays}

Extracts of cytoplasmic or nuclear proteins were prepared, using established methods, from neuroblastoma (SK-N-SHSY5Y; ATCC, USA), glioma (U138MG; ATCC, USA), and astrocytoma cell lines (STTG1; ATCC, USA). ${ }^{18}$ Electrophoretic mobility shift assay (EMSA) experiments were done using a probe containing the rs367398 polymorphism. Single stranded oligonucleotides $\left(5^{\prime} \rightarrow 3^{\prime}\right)$ were $5^{\prime}$ end labelled with digoxigenin ( $5^{\prime}$-AGAGGGACAGGGAC $(\mathrm{T} \rightarrow \mathrm{C})$ GGGGCTTGGAGAAGG-3'), annealed to complementary oligomer (5'CCTTCTCCAAGCCCC $(\mathrm{A} \rightarrow \mathrm{G})$ GT-CCCTGTCCCTCT-3'). A $10 \mathrm{~g}$ aliquot of proteins was added to a final volume of $20 \mu \mathrm{l}$ of a mixture containing $20 \mathrm{mM}$ Tris- $\mathrm{HCl} \mathrm{pH} \mathrm{9.0,50} \mathrm{mM} \mathrm{NaCl,} 1$ mM EDTA, 5\% glycerol, l mM phenyl methylsulphonyl fluoride, $1 \mathrm{mM}$ dithiothreitol, $5 \mu \mathrm{g} / \mathrm{ml}$ leupeptin, $5 \mu \mathrm{g} / \mathrm{ml}$ aprotinin, $0.5 \mu \mathrm{g} / \mathrm{ml}$ bovine serum albumin, $2 \mathrm{mg} / \mathrm{ml}$ poly $(\mathrm{dIdC})$, and $20 \mathrm{pmol} / \mu \mathrm{l}$ probe, and the mixture was incubated for 25 minutes at room temperature before gel analysis. The complexes were separated on a 5\% nondenaturating polyacrylamide gel, and semi-dry electrophoretic transfer was carried out from gels to nitrocellulose membranes. Detection was as described by the supplier (Roche Diagnostics, Meylan, France).

\section{Construction of reporter plasmids}

The fragments containing the rs367398 C/T polymorphism were amplified by polymerase chain reaction (PCR) from genomic DNA of homozygous individuals using the forward and reverse primers for genotyping. ${ }^{16}$ Fragments were cloned using the T-easy plasmid kit (Promega, Madison, Wisconsin, USA). After excision of the fragments of interest by enzyme restriction and gel purification, the fragments were cloned into the Bham I site (upstream of the Firefly luciferase gene) of the pGL3-basic vector (Promega). The integrity of the inserts was confirmed by sequence analysis using the Taq Big Dye Terminator sequencing kit on an ABI 377 sequencer (Perkin-Elmer Applied Biosystems, Foster City, California, USA).
Table 5 Evaluation of the interaction of the rs 367398 CC genotype with the $\varepsilon 4$ allele of the APOE gene in the French population

\begin{tabular}{lll}
\hline $\begin{array}{l}\text { APOE*Notch } \\
\text { ( } \mathrm{p} \text { value) }\end{array}$ & $\begin{array}{l}\mathrm{CC} \text { versus } \mathrm{CT}+\mathrm{T} \\
\left(\mathrm{OR} \text { in } \varepsilon 4^{-}\right)\end{array}$ & $\begin{array}{l}\mathrm{CC} \text { versus } \mathrm{CT}+\mathrm{TT} \\
\left.\text { (OR in } \varepsilon 4^{+}\right)\end{array}$ \\
\hline 0.36 & $\begin{array}{l}0.95(0.67 \text { to } 1.36) \\
\mathrm{p}<0.79\end{array}$ & $\begin{array}{l}0.73(0.47 \text { to } 1.13) \\
\mathrm{p}<0.16\end{array}$ \\
\hline
\end{tabular}

APOE* Notch indicates the significance level of the interaction term included in the logistic regression model.

$\mathrm{OR}$, odds ratio; confidence intervals are in given parentheses.

\section{Cell culture and transfection experiments}

U138MG (ATCC) cells were maintained in Dulbecco's modified eagle's medium/F12 (1:1) (Gibco, Paisley, UK), supplemented with $10 \%$ fetal calf serum (Gibco) and $1 \times$ antibiotic/antifungal solution (Gibco). For transfection experiments, the cells were seeded at $2.5 \times 10^{5}$ cells per well in a 12 well culture dish. After 48 hours, cells were transfected using fugene 6 (Roche, Basel, Switzerland) at a ratio of 1:3, DNA:fugene for five hours. Cells were harvested 24 hours later and lysed in reporter lysis buffer (Promega, Southampton, UK). Firefly luciferase activities (LAf) and renilla luciferase activities (LAr) were measured sequentially using a dual luciferase reporter assay system (Promega) by luminometry. To adjust for any variation in transfection efficiency and DNA uptake, the relative luciferase activity (RLA) was calculated as RLA = LAf/LAr. At least triplicate of three independent transfection experiments were performed using fresh construct preparations.

\section{RESULTS}

The rs387071 (promoter) and rs367398 (5'-UTR) polymorphisms were initially tested in the two British populations. No significant differences for allele and genotype distributions were detected between these two populations. No differences for allelic and genotype distributions were observed for either polymorphism between control and Alzheimer populations (tables 1 and 2). No modulator effects of age or sex were observed. However, a significant interaction between the rs367398 CC genotype and the APOE gene $\varepsilon 4$ allele was detected in the Manchester population and a similar trend in the Scottish population (table 3). The risk of developing Alzheimer's disease associated with the $\varepsilon 4$ allele was significantly higher for individuals bearing the rs367398 CC genotype than for those bearing the CT+TT genotypes (odds ratio, 5.83 (95\% confidence interval, 3.48 to 9.79) $v 1.92$ (1.21 to 3.06$)$, respectively). No variation in haplotype distribution was observed in the whole population, but this distribution was significantly different when studying individuals bearing at least one $\varepsilon 4$ allele $(p=0.0007)$. However, a haplotype combination of the two notch polymorphisms was not more informative than the effect observed for the rs367398 by itself.

To replicate these results, we tested the validity of the interaction of the promoter CC polymorphism with the $\varepsilon 4$

Table 4 Allele and genotype distribution of the rs 367398 NOTCH4 polymorphism in the French population

\begin{tabular}{|c|c|c|c|c|c|c|}
\hline \multirow[b]{2}{*}{ rs367398 } & \multirow[b]{2}{*}{$\mathrm{n}$} & \multicolumn{2}{|c|}{ Allele distribution (\%) } & \multicolumn{3}{|c|}{ Genotype distribution (\%) } \\
\hline & & C & $T$ & CC & CT & $\pi$ \\
\hline $\begin{array}{l}\text { Alzheimer' } \\
\text { cases } \\
\text { Control }\end{array}$ & $\begin{array}{l}436 \\
569\end{array}$ & $\begin{array}{l}570(0.65) \\
759(0.67)\end{array}$ & $\begin{array}{l}302(0.35) \\
379(0.33)\end{array}$ & $\begin{array}{l}186(0.43) \\
252(0.44)\end{array}$ & $\begin{array}{l}198(0.45) \\
255(0.45)\end{array}$ & $\begin{array}{l}52(0.12) \\
62(0.11)\end{array}$ \\
\hline
\end{tabular}


Table 6 Impact of the rs 367398 NOTCH4 polymorphism on $A \beta$ load according to APOE genotype

\begin{tabular}{|c|c|c|c|c|}
\hline & $\mathbf{n}$ & Aß40 (\% area) & | Aß42 (\% area) & Total $\mathrm{A} \beta$ (\% area) \\
\hline \multicolumn{5}{|l|}{ Total } \\
\hline CC & 31 & $3.7(4.0)$ & $10.8(4.9)$ & $14.7(7.5)$ \\
\hline CT & 44 & 3.8 (3.4) & $9.8(4.1)$ & $13.7(6.5)$ \\
\hline$\Pi$ & 13 & $3.7(4.0)$ & $10.6(4.7)$ & $14.3(7.5)$ \\
\hline \multicolumn{5}{|c|}{$\ln \varepsilon 4^{-}$} \\
\hline $\mathrm{CC}$ & 10 & $3.6(3.3)$ & $10.8(5.5)$ & $14.4(8.4)$ \\
\hline CT & 13 & $1.8(1.2)$ & $9.6(4.4)$ & $11.4(5.0)$ \\
\hline$\pi$ & 5 & $1.3(1.2)$ & $11.2(4.1)$ & $12.4(4.0)$ \\
\hline \multicolumn{5}{|l|}{$\ln 4^{+}$} \\
\hline$C C$ & 21 & $4.0(4.4)$ & $10.9(4.3)$ & $14.8(7.2)$ \\
\hline CT & 31 & $4.7(3.7)$ & $9.9(4.0)$ & $14.6(6.8)$ \\
\hline$\pi$ & 8 & $5.3(4.4)$ & $10.3(5.3)$ & $15.5(7.5)$ \\
\hline
\end{tabular}

allele in another large association study. As already reported in the British population, we did not observe any effects of the rs367398 Notch 4 polymorphism on the risk of developing Alzheimer's disease in a French population (table 4). However, we were not able to detect an interaction among any of the variables we tested in a model of logistic regression, in particular the APOE 84 allele (table 5).

We then assessed the functionality of the rs 367398 Notch 4 polymorphism by testing the impact of this polymorphism on $A \beta$ load in Alzheimer's disease brains, but no effect was detected, even when stratified according to APOE genotype (table 6). We next considered whether the rs367398 C/T polymorphism itself had a relevant biological role. We used EMSA to determine an allele dependent protein binding to the sequence containing this polymorphism. However, we were not able to detect a specific binding of either nuclear or cytoplasmic proteins extracted from SK-N-SH SY5Y, STTGI, or U138-MG cells (data not shown). We finally investigated whether this polymorphism was associated with an altered expression of a reporter gene in vitro. Even though a fragment containing the polymorphism of interest could induce an average sixfold higher transactivation than an empty plasmid, no significant difference was observed in relation to the alleles of the rs367398 NOTCH 4 polymorphism in the U138MG cell line. Altogether, these data suggested that the $\mathrm{rs} 367398 \mathrm{C} / \mathrm{T}$ is not located in a regulatory sequence within the Notch promoter and as a result is not functional in these conditions.

\section{DISCUSSION}

Characterisation of new genetic determinants for Alzheimer's disease is difficult. Even if genome linkage studies allow better detection of loci containing candidate genes of potential interest, the vast (genetic) length of these loci restricts the ease of identifying true causative genes. Hunting for a causative gene on chromosome 6 clearly illustrates this problem as the "true" gene, in close linkage with the HLA-A2 or TNF- $\alpha$ variants, may be any number of genes located within this locus of interest. The linked region is large-from $6 \mathrm{p} 21$ to $6 \mathrm{q} 12$-and at least 960 putative open reading frames are listed in the NCBI website (June 2002 assembly).

With this in mind, we focused our interest near the two candidate genes in the $\mathrm{MCH} 6 \mathrm{p} 21.3$ region for which an association had been reported-HLA-A and TNF $\alpha^{4}{ }^{6}$ However, because there are discrepancies in the few association studies that have been carried out on these genes, we do not know whether they really play a role in Alzheimer's disease. In the vicinity of HLA-A and TNF $\alpha$ is the NOTCH4 gene which is potentially a good candidate gene, for the reasons previously described.
We investigated the impact of the rs387071 (promoter) and rs367398 (5'-UTR) polymorphisms in NOTCH4 gene in a British population of Alzheimer cases and controls. We found no association with rs387071. We did detect a significant interaction of the rs 367398 CC genotype with the $\varepsilon 4$ allele of the APOE gene. However, we could not replicate this observation in a large independent French cohort. Furthermore, we were not able to establish a correlation between the rs367398 NOTCH4 polymorphism with A $\beta$ load in the brains of patients with Alzheimer's disease. We have also shown that the rs367398 polymorphism did not influence expression in vitro.

It is difficult to interpret the discrepancy observed between the British and French populations. It may result from a type I or type II error (that is, false positive or false negative, respectively). However, because the rs367398 polymorphism does not appear to be functional under our experimental conditions, it is likely that we can exclude it as a genetic determinant of Alzheimer's disease. It is interesting to note that in previous studies the potential impact of an unknown gene within the MCH $6 \mathrm{p} 21.3$ locus was determined as most important, or only present, when associated with the APOE \&4 allele, ${ }^{219} 20$ but such an interaction was not reported by others. ${ }^{4578}$ Consequently, the findings we have described in the British population may result from linkage disequilibrium of the rs367398 NOTCH4 polymorphism with another genetic variation in the NOTCH4 gene itself, or in another gene nearby. As linkage disequilibrium between two genetic markers in white (Europid) populations can vary strongly, ${ }^{21}{ }^{22}$ this association might not exist in French populations.

\section{Conclusions}

No association of two NOTCH4 polymorphisms alone was observed in one French and two United Kingdom populations, but evidence of an increased risk associated with the rs367398 CC genotype in $\varepsilon 4$ bearers was detected in the United Kingdom. However, as we were not able to determine functionality for this polymorphism, it is likely that the interaction is spurious or results from a linkage disequilibrium of this promoter polymorphism with another marker elsewhere in the 6p21.3 locus. This is consistent with the findings of others who have reported an association of genes within this region with Alzheimer's disease in $\varepsilon 4$ bearers, though not all investigators have found such a relation.

\section{Authors' affiliations \\ J-C Lambert, L Araria-Goumidi, M-C Chartier-Harlin, D Cottel, P Amouyel, INSERM 508, Institut Pasteur de Lille, Lille Cédex, France J Harris, C Lendon, Molecular Psychiatry Department, Queen Elizabeth Psychiatry Hospital, University of Birmingham, Birmingham, UK D Mann, Clinical Neuroscience Research Group, Department of Medicine, Greater Manchester Neurosciences Centre, Salford, UK T Iwatsubo, Department of Neuropathology and Neuroscience, University of Tokyo, Tokyo, Japan}

Competing interests: none declared

\section{REFERENCES}

1 Farrer LA, Cupples LA, Haines JL, et al. Effects of age, sex, and ethnicity on the association between apolipoprotein $\mathrm{E}$ genotype and Alzheimer disease. A meta-analysis. APOE and Alzheimer Disease Meta Analysis Consortium. JAMA 1997;278:1349-56.

2 Myers A, Wavrant De-Vrieze F, Holmans $P$, et al. Full genome screen for Alzheimer disease: stage II analysis. Am J Med Genet 2002;1 14:235-44.

3 Blacker D, Bertram L, Saunders AJ, et al. Results of a high-resolution genome screen of 437 Alzheimer's disease families. Hum Mol Genet 2003;12:23-32.

4 Zareparsi S, James DM, Kaye JA, et al. HLA-A2 homozygosity but not heterozygosity is associated with Alzheimer disease. Neurology 2002;58:973-5.

5 Harris JM, Cumming AM, Craddock N, et al. Human leucocyte antigen-A2 increases risk of Alzheimer's disease but does not affect age of onset in a Scottish population. Neurosci Lett 2000;294:37-40. 
6 Collins JS, Perry RT, Watson B, et al. Association of a haplotype for tumor necrosis factor in siblings with late-onset Alzheimer disease: the NIMH Alzheimer Disease Genetics Initiative. Am J Med Genet 2000;96:823-30.

7 Araria-Goumidi L, Lambert JC, Cottel D, et al. No association of the HLA-A2 allele with Alzheimer's disease. Neurosci Lett 2002;335:75-8.

8 Infante J, Llorca J, Berciano J, et al. No synergistic effect between -850 tumor necrosis factor-alpha promoter polymorphism and apolipoprotein E epsilon 4 allele in Alzheimer's disease. Neurosci Lett 2002;328:71-3.

9 Hitoshi $\mathrm{S}$, Alexson T, Tropepe $\mathrm{V}$, et al. Notch pathway molecules are essential for the maintenance, but not the generation, of mammalian neural stem cells. Genes Dev 2002; 16:846-58.

10 Irvin DK, Zurcher SD, Nguyen T, et al. Expression patterns of Notch1, Notch2, and Notch3 suggest multiple functional roles for the Notch-DSL signaling system during brain development. J Comp Neurol 2001;436:167-81.

11 Joutel A, Corpechot C, Ducros A, et al. Notch3 mutations in CADASIL, a hereditary adult-onset condition causing stroke and dementia. Nature 1996;383:707-10.

12 Wei J, Hemmings GP. The NOTCH4 locus is associated with susceptibility to schizophrenia. Nat Genet 2000;25:376-7.

13 Fan JB, Tang JX, Gu NF, et al. A family-based and case-control association study of the NOTCH4 gene and schizophrenia. Mol Psychiatry 2002;7:100-3.

14 Iwatsubo T, Odaka A, Suzuki N et al. Visualization of A beta 42(43) and A beta 40 in senile plaques with end-specific $A$ beta monoclonals: evidence that an initially deposited species is A beta 42(43). Neuron 1994;13:45-53.
15 Hixson JE, Vernier DT. Restriction isotyping of human apolipoprotein E by gene amplification and cleavage with Hhal. J Lipid Res 1990;31:545-8.

16 Ujike H, Takehisa Y, Takaki M, et al. NOTCH4 gene polymorphism and susceptibility to schizophrenia and schizoaffective disorder. Neurosci Lett 2001;301:41-4.

17 MacLean CJ, Morton NE. Estimation of myriad haplotype frequencies. Genet Epidemiol 1985;2:263-72.

18 Dignam JD, Lebovitz RM, Roeder RG. Accurate transcription initiation by RNA polymerase II in a soluble extract from isolated mammalian nuclei. Nucleic Acids Res 1983;11:1475-89.

19 Payami H, Schellenberg GD, Zareparsi S, et al. Evidence for association of HLA-A2 allele with onset age of Alzheimer's disease. Neurology 1997:49:512-18.

20 McCusker SM, Curran MD, Dynan KB, et al. Association between polymorphism in regulatory region of gene encoding tumour necrosis factor alpha and risk of Alzheimer's disease and vascular dementia: a case-control study. Lancet 2001;357:436-9.

21 Lambert JC, Araria-Goumidi L, Myllykangas L, et al. Contribution of APOE promoter polymorphisms to Alzheimer's disease risk. Neurology 2002;59:59-66.

22 Lazarus R, Klimecki WT, Palmer $\amalg$, et al. Single-nucleotide polymorphisms in the interleukin-10 gene: differences in frequencies, linkage disequilibrium patterns, and haplotypes in three United States ethnic groups. Genomics 2002;80:223-8.

\section{HISTORICAL NOTE}

\section{Silas Weir Mitchell and the "rest cure"}

W eir Mitchell ${ }^{1}$ (1829-1914), the American neurologist, renowned for his work on causalgia, was also interested in hysteria. He first encountered it in soldiers during the civil war.

In civilian practice when faced with patients with neurosis and hysteria he developed his "rest cure". It was based, he said, on moral and physical components described in his book Fat and blood ${ }^{2}$; the title reflected his experience that women with hysteria were often thin and anaemic. In addition to rest he insisted on removing the patient from their environment, asking them to write their life history, and using exercise, electrical stimulation, and a nutritious diet. In his hands, a rest cure was a success, perhaps owing to his patients' immense respect and faith in him. But Weir Mitchell was wise enough to anticipate and thereby prevent what we now label illness behaviour:

"...to lie abed half the day and sew a little, and read a little, and be interesting and excite sympathy, is all very well, but when they are bidden to stay in bed a month, and neither to read, write nor sew, and to have one nursewho is not a relative - then rest becomes for some women a rather bitter medicine and they are glad enough to accept the order to rise and go about when the doctor issues a mandate which has become pleasantly welcome and eagerly looked for."

Attending a lady, sick unto death, he dismissed his assistants from the room then soon left himself. Asked of her chances of survival he remarked:
"Yes she will run out of the door in two minutes; I set her sheets on fire. A case of hysteria."

His prediction thankfully proved correct.

"I urged, scolded and teased and bribed and decoyed along the road to health; but this is what it means to treat hysteria."

Weir Mitchell penned several classic books and papers. ${ }^{3}{ }^{4}$ He invented the term causalgia for the intractable pain consequent upon nerve injury. In Reflex paralysis ${ }^{5}$ he described the sudden weakness of the limbs on the side opposite to forebrain injury, thus anticipating the lateralisation of motor function by Fritsch and Hitzig by five years.

He studied postparalytic chorea, erythromelalgia (Weir Mitchell's disease), and deduced that the cerebellum augments and reinforces movement.

J M S Pearce

304 Beverley Road, Analby, Hull HU10 7BG, UK; jmspearce@freenet.co.uk

\section{References}

1 Pearce JMS. Silas Weir Mitchell (1829-1914) and causalgia. J Neurol Neurosurg Psychiatry 1990;53:763.

2 Mitchell SW. Fat and blood: an essay on the treatment of certain forms of neurasthenia and hysteria. London: Lippincot, 1884.

3 Mitchell SW, Morehouse GR, Keen WW. Gunshot wounds and other injuries of nerves. Philadelphia: Lippincott, 1864.

4 Mitchell SW. Injuries of nerves and their consequences. Philadelphia: Lippincott, 1872.

5 Mitchell SW. Reflex paralysis, the result of gunshot wounds and other injuries of nerves. Philadelphia: Lippincott, 1864. 